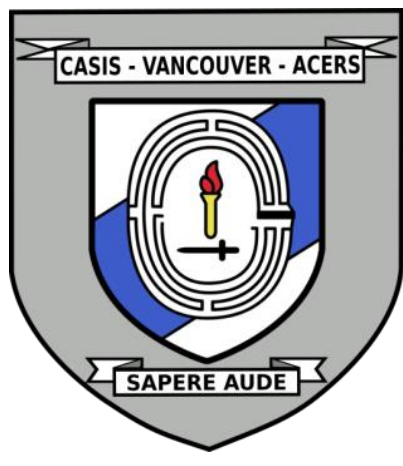

\title{
ARCTIC SECURITY AND DEFENCE IN A COMPETITIVE WORLD
}

Date: November 22, 2021

Disclaimer: This briefing note contains the encapsulation of views presented by the speaker and does not exclusively represent the views of the Canadian Association for Security and Intelligence Studies.

\section{KEY EVENTS}

On November 22, 2021, Dr. Andrea Charron, Director for the Center for Defence and Security Studies at the University of Manitoba, presented on Arctic Security and Defence in a Competitive World at the 2021 CASIS West Coast Security Conference. The primary focus of Dr. Charron's presentation was on three key areas of questioning the competitiveness of international order within Arctic security and defence. These areas were: competition, decision makers, and fora for navigating competition. The presentation was followed by a question and answer period with questions from the audience and CASIS Vancouver executives.

\section{NATURE OF DISCUSSION}

\section{Presentation}

The overarching theme of Dr. Charron's presentation was centered around the increased competition and geopolitics in the Arctic. Her presentation discussed this security concern by outlining the parameters of competition and assessing the significant role and influence of various decision-making authorities. Dr. Charron illustrated the significance of the Arctic not as a catalyst for conflict, but rather as a susceptible area to the secondary effects of conflict elsewhere.

\section{Question Period}

The question period highlighted the importance of avoiding a vacuum approach of reporting information regarding the Arctic directly from Ottawa without consultation with Northerners. In order to promote dialogue and meaningful, thoughtful political policy in the Arctic, it is vital for Canadians to understand 
the Arctic and the needs of the Indigenous populations and infrastructure deficits in the high north. The importance of the Arctic Council as an important forum for dialogue given growing tensions between the United States, Russia, and China in other issue areas was also discussed.

\section{BACKGROUND}

\section{Presentation}

Dr. Charron's presentation on Arctic Security and Defence in a Competitive World, began by proposing three key questions: what do we mean by competition? Who are the decision makers? And what are the fora for navigating competition?

Dr. Charron noted that strategic competition in the world happens in three different areas: political, economic, and military. In other words, strategic competition can occur in all three areas, but ultimately, competition is about regional influence. Competition in the Arctic is similar to that in the rest of the world. However, the advantage the Arctic has is the Arctic Council, which was created before reaching this new level of strategic competition. The Arctic Council, therefore, focuses on non-military issues including environmental protection, and sustainable development. Although the Arctic Council tries to focus on solving transArctic problems rather than politics, conflict is now more likely to happen as competition seeks to change norms and the rules of world order. An example is Russia and China as they attempt to reorder the norms and rules in a way that will benefit them that could affect the Arctic. Trust is an important element to ensure that competition stays at a healthy, stable state and so continued promotion of cooperation between Arctic states is helpful to the Arctic and elsewhere.

Dr. Charron pointed out that the United States, Russia, and China all have Arctic strategies. Additionally, she noted that the United States has strategies for each of its military services particular to the Arctic but not for other hotspots, such as the Middle East or Indo Pacific regions, which, arguably, are more strategically important. Dr. Charron argued that the United States does this to emphasize the importance of homeland protection.

Although the combination of state actors involved in the Arctic geopolitics might seem problematic (combination of NATO and non-NATO states, all of the P5 members, and many European and Asian observer states), all of these actors are part of the Arctic Council, which is very prescriptive about the roles of each state 
and have clear rules about their participation. There are eight Arctic States and six Indigenous Permanent Participants which have decision-making status. Thirteen other states - a combination of European and Asian states-are observer states. In addition, the Arctic Council does most of its work via six scientific working groups that include observer and Arctic states focused on transArctic issues, such as black carbon pollution or accident preparedness.

Furthermore, Dr. Charron highlighted that one should not underestimate the importance of other fora and agreements that have been created as a result of the Arctic Council. For example, the Arctic Coast Guard Forum, which is a mixture of safety, security, and military representatives from the eight Arctic statesFinland, Sweden, Denmark, Canada, Norway, Iceland, Russia, and the United States-focuses on best practices for search and rescue and oil spill clean ups.

Canada also has the Canadian Arctic Security Working Group, which discusses issues of shared interest and creates linkages between Canadian safety, security and defence organizations and academia. It is worth noting that Russia is not presently invited to Arctic security fora, such as the Arctic Security Forces Roundtable and the Arctic Chief of Defence Staff (on hiatus since 2014). Dr. Charron mentioned that the reason there has been great resistance from Western states to include Russia back into these organizations is because it could be perceived as an acceptance of Russia's egregious behaviours in other areas of the world. Although many academics have noted that this course of action is only increasing tensions and punishing the Arctic, Dr. Charron noted that there are several sanctions in place that make this a very difficult situation to deal with and accepting Russia back would be a violation of these sanctions and not without political ramifications.

Dr. Charron ended her presentation by pointing out some the considerations she believes are worth keeping in mind: encouraging Russia and the United States to return to the Open Skies' Treaty, which would increase trust between various parties; putting people first when making decisions about the Arctic; continuing to promote cooperation in other issue areas and not change the Arctic Council to add military and security issues to the agenda; and start thinking about a fora to deal with enforcement of laws and rules that apply in the Arctic.

\section{Question Period}

During the question and answer period, a question was raised on whether military-security dialogue is necessary to mitigate great-power competition in the Arctic as non-Arctic states, such as China, express interest in maintaining 
security in the region. Dr. Charron noted that one should be careful about the context on how conversations regarding China are framed as often the language used to describe China's role in the Arctic is erroneous. Failing to consider this, could result in China using it in a way that other Arctic states might not be prepared to limit the consequences. For example, China is not a near Arctic state nor a "permanent" observer, but it is sometimes referred to as such. Dr. Charron emphasized that, currently, the best method to engage with China is via the Arctic Council as an Observer.

With respect to how Canada can take the lead on ensuring safe shipping in the Arctic, especially Canada's Arctic, Dr. Charron noted that Canada should always take into consideration Indigenous perspectives. Furthermore, it is important to have conversations with Indigenous peoples when engaging in exercises on Indigenous lands (for example annual Op Nanook exercises) and when dealing with issues that affect them directly. Indigenous peoples' knowledge about the land and environment is essential to navigating this difficult landscape. In a way, Dr. Charron noted, Canada is far ahead and setting an example for other Arctic states with its Canadian Rangers program, which is part of the Canadian Armed Forces (CAF) Reserves, providing an important presence in Canada's remote areas and assisting the $\mathrm{CAF}$.

When asked what role she thought educational institutions have to contribute to Arctic security, Dr. Charron suggested that these institutions have the opportunity to provide an alternate lens to studying the security concerns in the Arctic. It is important to refrain from framing Arctic security through an exclusively military lens. An alternative approach suggested by Dr. Charron included a populationcentric approach and consideration of local communities' input in relation to environmental security.

\section{KEY POINTS OF DISCUSSION}

\section{Presentation}

- Strategic competition is the challenge by state actors in political, economic, and military areas.

- Trust is critical when promoting cooperation between Arctic states.

- The United States has pivoted more attention to the Arctic as evidenced by new Arctic strategies.

- Permanent participants and scientific working groups of the Arctic Council play an important role in decision making regarding the Arctic. 
- Currently, Russia is not part of some of the trust building Arctic fora, and although some academics argue that this is only increasing tensions, accepting Russia back into these fora would have political consequences.

\section{Question Period}

- There should be careful consideration on how conversations regarding China are framed. They are observers of the Arctic Council, not decision-makers.

- Canada should always consider Indigenous perspectives and include Indigenous peoples in conversations about issues that affect them directly.

- It is important to refrain from framing Arctic safety and security through an exclusively military lens and have a population-centric approach by considering the input of local communities in relation to environmental security.

\section{(c) (†) $\ominus$}

EY NC ND This work is licensed under a Creative Commons Attribution-NonCommercial-NoDerivatives 4.0 International License.

(C) (ANDREA CHARRON, 2022)

Published by the Journal of Intelligence, Conflict, and Warfare and Simon Fraser University

Available from: https://jicw.org/ 